\title{
Selected Reference Books of 1990-91
}

\section{Eileen McIlvaine}

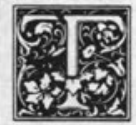

his article follows the pattern set by the semiannual series initiated by the late Constance M. Winchell more than thirty years ago and continued by Eugene P. Sheehy. Since the purpose of the list is to present a selection of recent scholarly and general works of interest to reference workers in university libraries, it does not pretend to be either well balanced or comprehensive. A brief roundup of new editions of standard works is provided at the end of the article. Code numbers (such as AD540, CJ331) have been used to refer to titles in Guide to Reference Books, 10th ed. (Chicago: American Library Assn., 1986).

\section{RARE BOOKS AND INCUNABULA}

Harvard University Library. A Catalogue of the Fifteenth-Century Printed Books in the Harvard University Library. Comp. by James E. Walsh. Binghamton, N.Y.: Center for Medieval and Early Renaissance Studies, SUNY at Binghamton, 1991. v.1 (in progress). (Medieval \& Renaissance Texts \& Studies, 84.) LC 90-6658.

Contents: v.1, Books Printed in Germany, German-Speaking Switzerland, and Austria-Hungary. 617p. \$32 (ISBN 0-86698-096-2).

Combing all the libraries under Harvard's aegis, including Dumbarton Oaks in Washington and Villa I Tatti in Florence, James Walsh has identified 1,281 incunabula printed in Germany, German-speaking Switzerland and Austria-Hungary. The arrangement follows Proctor (AA275), that is, chronological by date published under the name of the city. Each entry includes the author and transcribed title, format, number of leaves and foliation, leaf measurement in millimeters, copy specific variations, date and source of acquisition, and reference to other lists. There are concordances for Hain, Proctor, the Gesamtkatalog and Goff numbers (AA269AA273, AA275, AA279-AA280, AA278 respectively). Indexes include authors and anonymous titles, editors, translators, contributors, printers and places, provenance, identified bindings, and significant manuscript insertions.-E.Mc.

\section{BIOGRAPHY}

Black Biography 1790-1950: A Cumulative

Index. Alexandria, Va.: ChadwyckHealey, 1991. 3v. \$900 (ISBN 0-89887085-2). LC 91-254.

The monumental Black Biographical Dictionaries 1790-1950 (Chadwyck-Healey, 1987. 1068 fiche) reproduces some 31,000 biographies found in 297 biographical sources published before 1950. The compilers have excluded individual biographies and autobiographies but have included all collected biographies that could be located as well as "separately published books or pamphlets, whether histories, handbooks, yearbooks ... that have an identifiable chapter, section, or appendix devoted to collective biographies" (Introd.). The microfiche reproduces the sources, numbered 1-197, in alphabetical order by compiler so that it is well-nigh impossible to use without the index.

The index is arranged alphabetically by biography, providing dates, if known,

Eileen Mcllvaine is Head of Reference, Butler Library, Columbia University, New York, New York 10027. Although it appears under a byline, this column is a project of the reference departments of Columbia University Libraries, and notes are signed with the initials of these individual staff members: Barbara Sykes-Austin (Avery Library); Mary Cargill, Beth Juhl, Barbara Kemp, Robert H. Scott, Sarah Spurgin, Junko Stuveras (Butler Library). 
occupations, illustrations, if any, and references to the microfiche set by the number assigned. The key to the numbers, the handlist of titles which accompanies the microfiche set, is reproduced at the beginning of v. 3 of the index.

The index itself has indexes by place of birth, by occupation, by religion, and of women. The occupations are determinedly nonsexist-business person, military person, etc.-which can cause confusion. Is a female medical worker a nurse? And since doctors are usually identified as such, why is there no separate listing for them?

This set belongs in every research library, and any library answering questions on black biography should at least have access to this impressive achievement.-M.C.

\section{RELIGION}

Encyclopedia of Early Christianity. Ed. by Everett Ferguson. New York: Garland, 1990. 983p. \$95 (ISBN 0-8240-5745-7). LC 89-36997.

This encyclopedia provides a onevolume guide to the history of the Christian Church from the time of Christ roughly to the end of the sixth century. Containing a total of 977 articles by 135 contributors, it surveys a wide array of persons, texts, places, councils, doctrinal issues, heresies, and a host of related cultural and historical problems. Given the existence of so many encyclopedias and dictionaries of the Bible, however, strictly biblical material is discussed primarily in terms of its postbiblical development. Some attempt is also made to document the major figures, institutions, and publications involved in the study of this period. To be sure, there are some surprising lacunae: one searches in vain, for example, for any article on the Dead Sea Scrolls, the Essenes, Talmudic literature as a source on early Christianity, or Rudolf Bultmann. Nonetheless, overall coverage appears to be quite comprehensive.

Each article attempts to provide a brief overview of the background, development, significance, and current scholarship on its subject as well as bibliographic citations to key source publications and scholarly literature. The entries range from a paragraph or two to a few pages in length. A detailed subject index at the end of the volume provides additional access to the material. One feature that the nonspecialist reader, for whom this work is chiefly designed, may find confusing at first (since the explanatory note is buried in the introduction) is the practice of providing citations to patristic literature in the text by use of the often very laconic abbreviations employed by the Clavis Patrum Latinorum (BB309), Clavis Patrum Graecorum (BB311), and Thesaurus Linguae Graecae.

As noted, this is primarily a work for the nonspecialist, and it makes no attempt to supplant the many longer, more comprehensive or more detailed reference tools that already exist. (A list of some of these is provided at the end of the introduction to the book.) As such, the encyclopedia would seem to have a place in most general history and humanities reference collections. At the same time, as the editors suggest, its conciseness, currency, and offering of ready access to the major issues and key bibliographies may well make it of interest to specialists as well, particularly as an addition to a personal library.-R.H.S.

\section{LITERATURE}

\section{Letteratura Italiana. Gli autori: dizionario} bio-bibliografico e indici. Ed. by Giorgio Inglese et al. Torino, Einaudi, 1990-91. 2v. (1864p.) L110,000 each volume (ISBN 8806115030, 8806115049). LC 91-131315.

This bio-bibliographical dictionary completes the Letteratura Italiana, directed by Alberto A. Rosa, which started in 1982 and now comprises twelve volumes covering "writing" in Italy from the late fifth century to the present. Much emphasis is placed on studying literature in its historical and social contexts with practically every school of critical approach covered. The series is a most comprehensive treatment of literature from sermons and orations, scientific communications, and historiography to novels and drama.

The two final volumes, Gli autori, serve as a general index to the entire series with extensive cross references to 
previous volumes under each entry. The entries, totaling 7,500 items, address literary authors but also historians, critics, scholars, journalists, bearers of oral tradition, copyists, printers, publishers, book collectors, anonymous works under their titles, literary and cultural periodicals, academies (p. 7-13), libraries (p. 273-84), and cultural institutions. Each signed entry gives biographical details and is accompanied by a bibliography containing archival sources, works by and about the subject, along with the above-mentioned cross references.-J.S.

\section{Literary Exile in the Twentieth Century: An} Analysis and Biographical Dictionary.

Ed. by Martin Tucker. Westport, Conn.: Greenwood, 1991.854 p. $\$ 99.50$ (ISBN 0-313-23870-7). LC 89-25920.

In the preface to this volume, the editor defines literary exiles as including "writers who have suffered the experience of banishment, deportation, voluntary departure (with varying degrees of hope and/or expectation of return), flight from possible imprisonment or torture, or flight from incarceration for reasons of expression of belief." With entries for 550 writers from nearly every country, it includes all the writers one could expect to find (Jerzy Kosinski, Bessie Head, Elie Wiesel, Salman Rushdie) and many others (Susan Sontag, Noel Coward, Sam Shepard, Octavio Paz). Well-written entries, addressing themes of exile and alienation, are followed by brief bibliographies of secondary materials. Appendixes list major events that resulted in emigration and exile; writers by point of departure and point of arrival; and writers by type of exile (e.g., cultural, legal, political, etc.). The volume is indexed by person.-S.S.

\section{ARCHITECTURE}

Teague, Edward H. World Architecture Index: A Guide to Illustrations. Westport, Conn.: Greenwood, 1991. 447p. Art Reference Collection 12. \$65 (ISBN 0-31322552-4). LC 91-7565.

The World Architecture Index "is a reference tool for finding images of approximately 7,200 architectural works reproduced in more than 100 books likely to be available in libraries with architectural collections. The index is international in coverage, includes a variety of architectural, engineering, and planning works, and covers most historical periods and styles. Citations to reproductions of exterior and interior views, plans, sections, and elevations are provided, and access is enabled by index to building site, architect, type of work, and name of work" (p.ix).

The arrangement of the volume is in four sections. The first, the site index, forms the main body of the index and provides full information for locating reproductions. Entries are listed alphabetically by city or site and country and give the architect(s), if known, date of the work, the type of illustration, and reference to a book identified by a three-letter code (explained at the beginning of the volume). Part II, the architect index, lists architects, their dates, and their works and locations for reference back to the site index. Part III, the type index, refers to building types. Cross-references from unused forms of entry to building types used are provided within this index as well as in the site index (e.g., Agoras, see Open Spaces). Finally, a work index lists individually built works followed by location, again for referral back to the site index.

This is a useful tool for locating images of many important works of architecture. This reviewer hopes that further work will supplement this initial collection with many more published sources containing hundreds more architectural masterpieces not included here.-B.S.-A.

\section{CITY PLANNING}

Venturi, Marco. Town Planning Glossary: 10,000 Multilingual Terms in One Alphabet for European Town Planners/Stadtplanungsglosar/Glossaire d'Urbanisme| Glosario de urbanismo/Glossario di urbanistica. Munich: K. G. Saur; Venice: Arsenale, 1990. 277p. \$56 (ISBN 3-59810903-2).

This work is intended primarily for the use of professional planners, but can be useful for graduate students in urban 
planning, political science, sociology, and other related fields who must work with literature in several European languages. As stated in the subtitle, it includes 10,000 multilingual terms in a single alphabet (i.e., 2,000 terms $x$ five languages: English, German, French, Spanish, and Italian) commonly used by town planners, principally those who are preparing for the European economic integration in 1992.

Since the intended audience is already working in the field, "definitions of the terms used were deemed unnecessary, insofar as they are presumably already known to the users ..." (p.v). This decision, while perhaps more efficient from an editorial standpoint, renders the work less useful in one of several respects than Elsevier's Dictionary of Physical Planning in Six Languages (English, French, Italian, Dutch, German, and Swedish), compiled by Gordon Logie in 1989 (New York: Elsevier Science Pub., 1989. 468 p.). Logie's work may be preferable for academic libraries not only for having more languages and definitions where needed but also because it has more terms: 3,565 English-language terms and phrases are listed alphabetically with the foreign equivalents identified under each entry, giving a total of over 17,000 items. Each language is identified by an initial code placed next to the foreign term. In Venturi's glossary these are presented sequentially in varied typeface without the languages being identified. Elsevier's Dictionary then provides separate indexes for the foreign terms with reference back to the numbered English entries, a method Venturi considers tedious (p.v).

Both titles are comparable in the scope of subjects included in planning, an interdisciplinary field concerned with housing, transportation, urban design, economics, the environment, population, land use, public policy, building and construction, architecture, etc. The greater number of entries and the inclusion of some idiomatic expressions give Elsevier's Dictionary the edge here too, although Venturi's stated purpose was "not .... to be a complete guide to terms in the discipline but rather to cover the cross-currents between specific forms of knowledge and operational areas." These are intended in the future to "be built on by creating customized supplements to specific sectors ..." (p.v). Here again, Logie's earlier work for Elsevier, a series of five international planning glossaries published between 1978 and 1986 in the same six languages as the Dictionary, may already provide adequate coverage of existing terminology. The five Elsevier glossaries are Glossary of Population and Housing (CG36), Glossary of Transport (CH444), Glossary of Employment and Industry (CH708), Glossary of Land Resources (CL78), and Glossary of Planning and Development (1986, volume 5 in the series).

As new planning practices and theories come into existence, however, continued efforts to understand and communicate differing cross-cultural and multinational approaches to urbanization and the built environment will be welcome and needed.-B.S.-A.

\section{WOMEN'S STUDIES}

Cole, Helena. The History of Women in Germany from Medieval Times to the Present: Bibliography of English-Language Publications. Washington, D.C.: German Historical Institute, 1990.102p. (Reference Guides of the German Historical Institute, 3.) \$5. LC 91-209584.

This smal!, inexpensive book may be the reference bargain of the year. Compiled by the German Women's History Study Group, it is a classified list of books, articles, and essays (unfortunately no dissertations are included) discussing all aspects-religious, cultural, political, and social-of German women's history. "All German-speaking areas are included until 1871, after which we took Germany as it was defined by its political borders. However, works on Austria are included until 1918 if they focus specifically on women. Neither Switzerland nor the Low Countries is covered" (Introd.).

The classification scheme is quite detailed and the sources wide-ranging. I was recently asked for information 
about German women's war work in the First World War, and a quick glance through the table of contents showed a chapter on World War I, which included articles on war work from two 1917 issues of the New York Times Magazine and one from a 1920 Monthly Labor Review, none of which is listed in Women in Western European History (CC561).

No reference work is perfect, and this one has no entries under individual names. Someone looking for sources on Rosa Luxemburg must scan several pages of entries of the section on "Politics and Law" for the period 18701918 , and several more pages for biographies from the same period. While a subject index would have solved this problem, this is a valuable addition to any collection supporting European history and/or women's studies.-M.C.

Feminist Legal Literature: A Selective Annotated Bibliography. Comp. by F. C. DeCoste, K. M. Munro, and Lillian MacPherson. New York: Garland, 1991. 499p. (Garland Reference Library of Social Science, 671) \$65 (ISBN 0-824071174). LC 91-9731.

Listing multidisciplinary journal articles dealing with legal issues of interest to feminists, this selective bibliography is not intended as a comprehensive list of legal literature regarding women and women's issues relevant to law. Instead, articles chosen for inclusion are written from a feminist perspective. Within these parameters; the compilers have concentrated on legal periodicals, alternative press publications, international human rights literature, and social sciences journals, generally from the 1980s. Most articles are in English, but French-language materials published in relevant French-Canadian publications are included.

The work is divided into broad chapters on such topics as "Abortion and Reproduction," "Family Laws," "Feminist Theory," and "First Nations and Race." Some of these broad topics are further subdivided within the chapters. The separate chapters on book reviews and bibliographies are the only entries for monographs. Although most entries have clear, concise annotations, the short chapters on bibliographies and symposia are unannotated; at least some of the individual articles in symposia do appear in the annotated topical chapters. Entries that could be listed in two or more categories are listed in each but fully annotated only in one.

Three indexes (personal/corporate name, periodical title, topical) provide additional access points. Unfortunately, weaknesses exist in this area of the book. There seem to be a few errors in the indexing itself, such as incomplete pagination. Headings are still very broad. Finer subject headings and the inclusion of geographical terms would have allowed users to pinpoint more accurately those articles relevant to their needs. References in the index are to page numbers alone. This practice means that the user must search each entry on the page in order to identify relevant items.

Overall, this work will be a valuable addition to any women's studies or legal collection, but its value would have been enhanced by more careful and complete indexing.-B.E.K.

Zuckerman, Mary Ellen. Sources on the History of Women's Magazines, 17921960: An Annotated Bibliography. Westport, Conn.: Greenwood, 1991. 297p. (Bibliographies and Indexes in Women's Studies, 12) $\$ 49.95$ (ISBN 0313-26378-7). LC 91-12151.

This comprehensive critical bibliography focuses on the history of popular American women's magazines, with chapters addressing women's magazines in general; the portrayal of women in the media; studies of content in women's magazines; the individuals working for women's magazines; advertising and ad agencies; surveys, marketing research reports, and promotional materials; the business of women's magazines; and selected archives and manuscript collections. Ten major magazines (Ladies' Home Journal, Woman's Day, McCalls, etc.) are treated individually, but the best way to find material on specific periodicals is to use the subject index. For the most part, 
the periodical publications of societies and organizations have been excluded, although some "entries dealing with more specialized journals, such as suffrage publications, appear primarily when they shed light on or provide contrast to the more mainstream publications"(Introd.). The book is indexed by author and subject.-S.S.

\section{POLITICAL SCIENCE}

The Columbia Dictionary of Political Biography. New York: Columbia Univ. Pr.; London: Economist Books, 1991. 335p. $\$ 40$ (ISBN 0-231-07586-3). LC 90-24439.

A compact and useful guide, this biographical dictionary provides ready access to information on several hundred individuals currently active on the world political scene, and as such promises to be useful to any library seeking to provide coverage of international affairs and current events. Researched and compiled for The Economist Books Ltd. by the Cambridge International Reference on Current Affairs, it is published in the United States by Columbia University Press. Included are heads of state and governments, ministers, legislators, prominent regional administrators, and other local government figures, trade unionists, leaders of major professional or nongovernmental organizations, lobbyists, and influential figures of other types.

The biographies are arranged alphabetically and, at the end of the book, the names are listed by country. Each brief sketch provides an overview of the individual's background and career as well as an attempt to characterize his or her accomplishments and point of view and to assess his or her place on the current political scene, thus providing more analysis and less of a detailed listing of facts than is found in the who's who type of biographical directory. No listing of sources or other bibliographical information is provided, however.

The work does an admirable job of representing all countries. Not too surprisingly, however, it emphasizes Europe and North America, with fullest coverage provided for the United States (241 biographies) and the United Kingdom (166), followed by the former Soviet Union (117), and France (112). It offers markedly less coverage of Germany (77) and Japan (46), to say nothing of such major Third World powers as China (35), Mexico (12), Egypt (10), or Brazil (11). It does, however, do a better job than any other single volume this reviewer has seen to date in keeping reasonably abreast of the ever-changing political actors of contemporary Eastern Europe.

The dictionary is quite current in its coverage, seeking, as it does, to document political leaders alive and active as of December 31,1990, and updating that with a "Stop Press" chronology at the beginning of the volume. Indeed, continuing to maintain that currency will surely be the ultimate test of this reference work. It appears that the editors do anticipate the production of updated versions, but it is not clear just how regular the appearance of subsequent editions is likely to be.-R.H.S.

\section{Encyclopedia of the Second World. Edited \\ by George Thomas Kurian. New York: \\ Facts On File, [1991]. 614p. \$145 (ISBN 0-18160-1232-6). LC 90-40370.}

This volume completes the series begun by Facts On File with its earlier encyclopedias of the First and Third Worlds, and those libraries that have already acquired those two titles will no doubt want this one as well to ensure comprehensiveness. As its title suggests, it provides coverage of what could have been described, until recently, as the Communist countries of the world, including the former Soviet Union, Eastern European Communist states, Mongolia, and the People's Republic of China but not North Korea, Vietnam, Laos, Cambodia, or Cuba, all covered in the Encyclopedia of the Third World (CJ212). Compiled by George T. Kurian with considerable assistance from John J. Karch and using a format familiar to readers of the other two encyclopedias, it offers lengthy articles (ranging from 24 pages for Albania to 128 pages for the Soviet Union) surveying the geography, history, political and economic systems, and educational and cultural affairs in 
each of those countries, concluding with a very brief chronicle of recent events and a bibliography of English-language sources.

As in any compendium of this kind, particularly one compiled by one or two individuals, the specialist reader will inevitably find some distortions, misstatements of fact, and peculiar or incorrect spellings (the latter particularly noticeable in the section on Poland). It is unfortunate, too, that the narrative historical sections break off with 1945, leaving readers to reconstruct their synthetic view of the events of the past five decades from the various analytic sections and the skeleton chronology at the end. Nonetheless, the book is an impressive achievement, providing ready access to detailed information on a host of questions and a useful format for a comparison of these often very diverse societies. Fairly recent statistical data (much of it for 1988) on such matters as population, work force, tourism, industry, agriculture, trade, health, education, and so forth are provided for the same periods for each country.

To be sure, the revolutionary changes of the last two years have rapidly overtaken and outdated the descriptions provided here. What seemed until only recently to be an unshakable feature of the world scene is melting away before our eyes, making it increasingly difficult to speak of this already very heterogeneous collection of countries as any kind of separate "world." One can hardly fault the authors here, of course. They have clearly made valiant efforts to bring parts of the text up to date, although not always with equal success. In any case, it will certainly be some time before such an encyclopedic compendium can be undertaken again (if, indeed, another work of this kind will ever be possible). For the meantime, however, the volume should serve as a useful takeoff point in making some sense of these societies as they abandon the ideological and institutional conformity that once united them and struggle to evolve new, individual forms of economic and political life.-R.H.S.
Roberts, Nancy L. American Peace Writers, Editors, and Periodicals: A Dictionary. Westport, Conn.: Greenwood, 1991. 362p. \$65 (ISBN 0-313-26842-8). LC 9023169.

Peace movements, which are quite heterogeneous phenomena, are here studied from the focal point of their relationships to journalism, communication, and the advocacy press in the nineteenth and twentieth centuries. Although adopting the form of a biographical dictionary, American Peace Writers provides a who's who of members of peace movements in the United States, a survey article on the American peace advocacy periodical press, a list of periodicals, a chronology of peace movements, a list of affiliations of the individuals listed to peace organizations, and a selected bibliography. It is indexed by name and topic.

A typical entry for a person includes brief biographical data (dates and places of birth and death, professional activities), peace activities, and a fairly substantial bibliography of works by and about the individual and the location of the archival resources (papers, oral history sources, etc.).

The section of advocacy periodicals lists names of publishers, editors, editorial board members, along with the publication data under each periodical title. An asterisk denotes that the person is included in the dictionary section.

In view of the importance of the media in shaping public opinion and policy, this work is a welcome contribution to peace studies.-J.S.

\section{FOLKLORE AND MYTHOLOGY}

Mythologies, Compiled by Yves Bonnefoy: $a$ Restructured Translation of Dictionnaire des Mythologies et des Religions des Sociétés Traditionnelles et du Monde Antique. Prepared under the direction of Wendy Doniger. Trans. Gerald Honigsblum and others. Chicago: Univ. of Chicago Pr., 1991. 2v. \$195 (ISBN 0-226-06453-0). LC 90-46982.

As editor Wendy Doniger firmly states in her preface,"This is ... certainly not an encyclopedia." Although the original Dictionnaire (Paris: Flammarion, 1981) 
was arranged in alphabetical form, it was "a quirky and idiosyncratic set of essays, long and short, by a particular group of mythologists, most of whom are French and all of whom participate in the French school of mythology in its broadest sense" (Pref.). Rather than a dispassionate survey, the French edition offered an uneven and arbitrary treatment of topics in mythology, concentrating, for instance, on Francophone Africa to the neglect of other cultures and omitting Judaism and Islam altogether. At the same time, it provided a "snapshot" of the influential French scholarship engendered by Claude Levi-Strauss and Georges Dumézil, which makes use of terminology and techniques from the disparate fields of semantics, literary criticism, anthropology, theology, linguistics, and sociology in the study of myth. Hoping to "minimize [the work's] weaknesses, emphasize its sometimes hidden strengths, and make it useful to the English-speaking reader in new ways," the French alphabetical arrangement has been reorganized into ten main sections covering Africa; the ancient Near East; Celts, Norse, Slavs, Caucasians, and their neighbors; Greece; Rome; Western civilization in the Christian era; South Asia, Iran, and Buddhism; Southeast Asia; East Asia and Inner Asia; and the Americas and the South Pacific. In addition, an introductory section covers the interpretation of mythology, mythography, and prehistoric religion.

Within each section are approximately fifty signed articles on specific topics, themes, characters, and motifs with copious illustrations. Entries range in length from two sentences (Rhadamanthys) to several thousand words (The Problem of Evil). Coverage is inconsistent: some chapters dwell at length on literary or psychological studies and motifs while others seem more taken up with ethnography or folklore. The organization of the work into geographical chapters makes for fascinating browsing but does require frequent consultation of the general index for discussion of particular themes or phenomena in different cultures. Most articles conclude with bibliographies, but Mythologies remains very much a work in translation-the bibliographies cite French translations of texts, rather than English versions. Another small bibliographic complaint is the lack of an author index or general bibliography: since so many of these articles were written by the most influential scholars working today, it would be nice to be able to locate, for instance, all the articles by Pierre Vidal-Naquet or Nicole Loraux.

This handsomely illustrated pair of volumes would be as at home on a coffee table as in the reference collection. Much like Joseph Campbell's monumental Historical Atlas of World Mythology (CF3), Mythologies may perhaps provide more pleasure to the browsing reader than to the harried reference librarian trying to chase down the genealogy of the minotaur. However, it does offer a wonderful collection of the important French scholarship of the last few decades, and will provide beginning students with an introduction to the current thinking and controversies in the study of mythology and religion.-B.J.

\section{HISTORY}

Historical Abstracts on Disk. v.38 (1987)v.42A, no. 1 (1991)[computer file]; and America History and Life on Disk v.24 (1987) v.28, no. 2 (1991) [computer file]. Santa Barbara, Calif.: ABC-Clio, 1991. 4 3/4-inch computer laser optical disks. Three times a year, each disk cumulative. $\$ 2,000$ for each disk if a subscriber to the print version also, otherwise $\$ 2,750$ (different prices if networked).

For many years, the print versions of Historical Abstracts (DA19-DA21) and America History and Life (DB47) have been mainstays of bibliographic research for historians. The volumes are noted for their broad and comprehensive coverage of English-language major monographs, articles, and dissertations in the historical field, as well as for serious coverage of much major foreign-language literature. Nonetheless, those interested in focusing in quickly on a specific topic rather than browsing 
through broader subject categories have long been hampered by these publications' somewhat cumbersome and murky system of subject indexing. Given limitations of access and cost, use of the online database version of these indexes has not been a satisfactory alternative, despite the infinitely greater efficiencies of the latter method of searching. Hence, it is with considerable enthusiasm that librarians can greet the long awaited compact disk versions of both these publications, which promise to combine the power of electronic searching with the convenience and flexibility of consulting a reference tool locally rather than online.

The enthusiasm must be tempered, however, by two troubling facts. The first is the reported plan of the publisher, $\mathrm{ABC}-\mathrm{Clio}$, to limit the period of coverage on this disk to the last five years of indexing only. The second is the publisher's decision not to make use of any preexisting CD-ROM searching interface, but instead to come up with a customized software package of its own. As a result, end users will be forced to spend time learning (or, even more likely, being taught) yet another set of protocols rather than simply sitting down and beginning to search for the information they want. Moreover, the current version of the software has some slightly irritating features: no provision for searching by descriptor alone on the simpler onepage version of the search screen (it is included on a much more detailed multipage version that is less convenient to use); the need to use adjacency characters between elements in a string, even in the author field; narrow search fields, which can make the composition and editing of complex Boolean searches a cumbersome business; difficulty in comfortably and efficiently inserting terms from the indexes into the search fields; and an awkward print menu that is likely to trap the unwary user into printing an entire list of references rather than just the ones he or she wants.

All such problems aside, it is clear that this is one of the most significant (if not the most significant) additions to the store of electronic reference tools this year. It has been this reviewer's experience that, regardless of the difficulties of the current software, library patrons introduced to this product have embraced it enthusiastically as an alternative to the much more time-consuming consultation of the printed volumes. In time, particularly if the range of coverage were to increase, it is hard to imagine that any serious research library now subscribing to the printed versions of this product could resist obtaining the CD-ROM. Reference librarians can only hope that, if switching to one of the standard interfaces is impossible, at least subsequent updates of the software will address some of the aforementioned problems.-R.H.S.

\section{Oxford Dictionary of Byzantium. Ed.-in-}

chief, Alexander P. Kazhdan. New

York: Oxford Univ. Pr., 1991. 3v. \$275

(ISBN 0-19-504652-8). LC 90-23208.

The Byzantine Empire, which endured for at least twelve centuries and extended at its zenith from Gibraltar to Armenia, from the Danube to the Nile, remains a large lacuna in the minds of most people otherwise well-versed in the intricacies of European history. Indeed, even our term Byzantine is a misnomer, as the inhabitants of Constantine's realm never thought of themselves as anything other than the legitimate successors to the Roman Empire. The curious student or researcher might find some helpful information about Byzantium in recent reference books such as the Dictionary of the Middle Ages (DA164), and several bibliographic compendiums in various languages have been issued throughout this century. However, until now, nocomprehensive, up-to-date Englishlanguage source existed; this omission left beginning students to confront a bewildering array of Russian, Greek, German, and French monographs on particular topics.

The paucity of reference sources in any language-the aborted Reallexikon der Byzantinistik (Amsterdam: Hakkart, 196876) ceased after the publication of only six fascicles-makes the new Oxford Dictionary of Byzantium doubly welcome. 
Seven years in the making, this dictionary contains over 5,000 signed entries on the persons, institutions, geography, politics, arts, economics, and religions of the empire from the fourth through the fifteenth centuries. Articles vary in length from a paragraph to several pages, and all include short bibliographies of recommended texts, editions, or translations as well as secondary literature. Greek translations or transliterations are provided for most entries; cross-references to related articles are included in the text. Approximately fifty black and white maps and genealogical tables, as well as photographs and line drawings of art works, manuscripts, architecture, and portraits are scattered throughout the volumes.

Articles are for the most part wellwritten and concise, though many require a great deal of page-turning to track down all the cross-references to scholarly terminology or obscure persons or places (e.g., chrysobull, proskynesis, automata, etc.). Though many of the entries are devoted to emperors and their courts, church prelates and theology, and all the appurtenances of the public realm, readers will enjoy the many articles on different aspects of the private life and customs of ordinary people, such as the entries on diet, wine, weddings, ink, beasts of burden, and childhood.

However, two defects may hinder the use of this work. The lack of an index forces readers to hunt through the three volumes for related articles on their topic. The second problem is the editorial choice of letter-by-letter, rather than word-byword alphabetization. This arrangement can cause articles on similar topics to be separated by nonrelated entries. For example, Arta (a town in Northwestern Greece) comes between "Art" and "Art and the West." Unfortunately, many browsers may never find the second, important entry unless they pay close attention to the cross-references in the first article.

Despite this minor difficulty and the more serious lack of an index, the Oxford Dictionary of Byzantium constitutes an important new resource and, for most large research collections, is well worth its hefty price.-B.J.

Seewann, Gerhard. Bestandskatalog der Bibliothek des Südost-Instituts, München. Munich: R. Oldenbourg, 1990. v.1 (in progress). (Südosteuropa-Bibliographie: Ergänsungsband 1). LC 91-166451.

Contents: Bd.1, Druckschriften 15291945. 850p. DM198 (ISBN3-486-55031-4).

The Südost-Institut in Munich is a state-supported, independent research institute, whose library collects material written in all languages about the history, politics, economics, and culture of Albania, Bulgaria, Yugoslavia, Romania, Czechoslovakia, and Hungary, and the Byzantine, Ottoman, and Hapsburg empires. This volume lists the Library's 80,000 books published from 1529 to 1945. Although intended as a guide to the library's holdings, its detailed table of contents and classified arrangement make it useful to scholars as a subject bibliography. The catalog also includes an alphabetical list, with detailed holdings, of the newspapers and magazines to which the library subscribes, and an alphabetical index of main entries (author, title, or corporate author). Any library supporting advanced research in this area should have this catalog.-M.C.

Stephens, W. B. Sources for U.S. History: Nineteenth-Century Communities. Cambridge: Cambridge Univ. Pr., [1991]. 558p. \$75 (ISBN 0-521-353157). LC 9037810.

For anyone familiar with Stephens's earlier work, Sources for English Local History (DC327), the news that he has turned his attention to U.S. local history will be most welcome. Preferring to use the term community history, Stephens defines his focus as "an identifiable entity . . occupying a particular territory smaller than a state-like a region, a county, a township or city, or perhaps a distinct part of a city" (Introd.).

The author discusses both the use of primary and secondary sources, published and unpublished: statistical, narrative, bibliographic, cartographic, or pictorial, carried out through topical 
chapters, e.g., "Education," "Poverty," "Health and Crime," "Manufacturing, Mining, and Business Activity." The religion chapter provides a good example of Stephens's method. First Stephens presents ideas for research, e.g., a history of an individual church or parish, the growth of regional administrative structures, the religious activities of northern churches in the South during Reconstruction, relations between ethnicity and religion, church attitudes toward morality or a controversy, etc. He then discusses the general primary and secondary sources, including denominational and business directories, travelers' accounts, sermons, maps and plans, photographs, general and denominational newspapers and periodicals. Sections then coverdenominational records and collections and sources for missionary work. The chapter ends with an examination of the usefulness of government records both federal and state (e.g., census) and county (e.g., probate records, marriage and death records, tax lists).

The index covers topics or themes addressed in the discussions but not to the examples or authors cited. For researchers (not necessarily academic) of nineteenth-century American history this guide will be of immense help.-E.Mc.

\section{NEW EDITIONS, SUPPLEMENTS, ETC.}

The Dictionary of Bias-Free Usage: A Guide to Nondiscriminatory Language, edited by Rosalie Maggio (Phoenix, Ariz.: Oryx, 1991. 293p., \$25), is a revised edition of The Nonsexist Word Finder (Oryx, 1987. 210 p.). This new edition has increased the number of words treated from about 3,000 to 5,000 (with 15,000 alternatives), expanded the "Writing Guidelines" portion, dropped the section of readings, and changed the bibliography to a brief paragraph, "For Further Reading," which cites a few of the important, more recently published books.

J. D. Douglas, known to reference librarians as the compiler of The New Bible Dictionary (BB174) and the New International Dictionary of the Christian Church (BB240), has turned his attention to the Schaff-Herzog Encyclopedia of Re- ligious Knowledge (BB63) by editing a new edition of the supplement, The 20thCentury Encyclopedia of Religious Knowledge (Grand Rapids, Mich.: Baker Book, 1991. 895p., \$39.95). The scope is limited to twentieth-century theology, biblical studies, church history, and comparative religion. It is "more consistently and intentionally evangelical in outlook, in viewpoint and interests .... [but] less American in orientation" (Pref.). Some entries, especially biographical ones, are repeated, other earlier entries are revised, bibliographies are updated. With new articles on contemporary issues, the work now contains 2,100 articles.

A supplement to World Authors (BD111, BD113, and 1975-1980 published in 1985) covering 1980 to 1985 has been compiled by Vineta Colby (New York: Wilson, 1991.938p., \$80), featuring prominent authors in this period from Edward Abbey to Zhang Xianliang, in order "to offer not only a biographical account but also a comprehensive survey of each author's achievement" (Pref.). The volume concludes with a list of the authors by nationality, pointing up the fact that the coverage is strongest for English-language speakers but also recognizing the great effort made to achieve an international sweep.

Revised is Contemporary Poets, edited by Tracy Chevalier ( 5 th ed. Chicago: St. James Pr., 1991. 1,179p., \$115; 3d ed., 1980 (BD639); 4th ed., 1985) in order to maintain currency. There is now an index of all books listed in the Verse section of each entry and an appendix with notes on the advisers and contributors.

A Dictionary of Literary Terms and Literary Theory edited by J. A. Cuddon (3d ed. [Oxford and Cambridge, Mass.]: Blackwell, [1991]. 1,051p., \$44.95; 1st ed. 1977 (BD53); rev. ed., 1979) is greatly expanded with much new material on literary theory, the theater, and forms of popular literature. It is still strong on cross-references, with no indexing.

The Reference Guide to English Literature edited by D. L. Kirkpatrick ( 2 d ed. Chicago: St. James Pr., 1991. 3v. 2,143p., \$250); 1st ed: St. James Reference Guide to English Literature, (1985. 8v.) looks very 
much like Contemporary Poets (BD639 and above), Contemporary Dramatists (BD222), and Contemporary Literary Critics (BD398) in that for each author it gives a brief chronology of the author, a complete list of published works with a select list of bibliographies and critical studies, and a signed critical essay. The difference is that this set addresses few living writers. The previous edition was arranged by broad periods, e.g., the beginnings of English literature and the Renaissance, and twentieth-century poetry. The present edition has introductory essays on periods and genres, but the authors are presented in alphabetical order, followed by a special section of discussion of specific novels. The book is indexed by title.

The New Arthurian Encyclopedia, edited by Norris J. Lacy (New York: Garland, 1991. Garland Reference Library of the Humanities 931.577 p., $\$ 80$ ), is virtually the same as its predecessor, The Arthurian Encyclopedia (1986), but with the addition of 500 entries.

Two hundred authors of German seventeenth-century literature have been thoroughly indexed by Gerhard Dunnhaupt in Personalbibliographien zu den Drucken des Barock (Stuttgart: A. Hiersemann, 1990-91. v.1-4 (Abele-Postel); to be in $6 v ., 660 \mathrm{DM}$ per volume). For each author, Dunnhaupt gives a biographical sketch and a complete bibliography of all original and translated works published up to the mid-eighteenth century. This edition is much expanded from the original Bibliographisches Handbuch der Barockliteratur (BD810). It is an amazing work: more than 700 libraries from all over Europe and North America have been surveyed; there is a listing of 1,200 bibliographies of bibliography.

A very welcome addition to the International Encyclopedia of the Social Sciences (CA51) is v.19, Social Science Quotations, compiled by David L. Sills and Robert K.Merton (New York: Macmillan, 1991. 437 p., \$90). Besides providing a vast number of quotations to "supplement the biography articles" and "to highlight some social science idea, theme or general finding" (Pref.), the volume is a very handy ready reference tool in its own right. Most admirable is the exact bibliographical reference to the source of the quote with page or paragraph. It is delightful to see that Professor Merton has included relevant quotations for "Standing on the shoulders of giants" with a neat twist in the most current expression of that term. The arrangement is alphabetical by author with a good subject index.

In 1991, PAIS Bulletin (CA35) and PAIS Foreign Language Index (CA33) merged to form PAIS International in Print (New York: Public Affairs Information Service. \$495). The coverage is the same: the same journals, the same types of monographs, and government publications. The editors state that about 80 percent of the new index will be English-language material, with French, German, Italian, Portuguese, and Spanish making up the rest. The foreign language citations always have a brief abstract (as do many of the English-language ones as well). The editor also points out that there are many more geographic headings in the merged index.

Frances Goins Wilhoit's Mass Media Bibliography: an Annotated Guide to Books and Journals for Research and Reference (Urbana, Ill.: Univ. of Illinois Pr.; Ithaca, N.Y.: Cornell Univ. Pr., 1990. 344p., $\$ 49.95$ ) is a revised and expanded edition of Eleanor Blum's Basic Books in the Mass Media (CH495). By dropping "basic" from the title as too restricting, Wilhoit has broadened the coverage of this third edition to 1947 entries with the majority of new titles published from 1980 to 1987.

Continuing the Great Historians series is Great Historians of the Modern Age: An International Dictionary, edited by Lucian Boia (Westport, Conn.: Greenwood, 1991. 841p. \$95) for the nineteenth and twentieth centuries. Perhaps because the editor is Romanian, the coverage seems to be much more international-9 historians for Africa (including Louis Leakey), 13 sketches for Arab historians, 12 for Austria, 29 English sketches, 20 Romanian sketches, etc. The table of contents does not list the biographies; it only lists the regional sec- 
tions, which is a nuisance. The book is indexed by name and subject.

The second edition of Jack Sweetman's, American Naval History: An Illustrated Chronology of the U.S. Navy and Marine Corps 1775-Present (Annapolis, Md.: Naval Institute Pr., 1991, 376p. \$36.95) has added coverage from April 28, 1984 to March $8-10,1991$, and an updated bibliography.

The Cambridge History of Latin America (DB281) is devoting volumes VI-IX to Latin America since 1930. Volume VIII (Cambridge: Cambridge Univ. Pr., 1991. 919 p. $\$ 89.50$ ) addresses itself to the his- tory of the nine republics: Argentina, Uruguay, Paraguay, Chile, Peru, Bolivia, Colombia, Ecuador, and Venezuela. Coverage for many of these countries comes up to the late 1980 s and 1990 .

A much expanded and updated version of G.S.P. Freeman Grenville's Modern Atlas of African History (London: Collings, 1976, 63p.) now covers from prehistoric times to 1990. The New Atlas of African History (London: Macmillan; New York: Simon \& Schuster, 1991. 144p., \$65) presents 103 relief maps and accompanying text. It is indexed by name and subject.

\section{IN FORTHCOMING ISSUES OF COLLEGE \& RESEARCH LIBRARIES}

The Emperor's New Clothes? Problems of the User Survey as a Planning Tool in Academic Libraries

Doris J. Schlichter and J. Michael Pemberton

Interdisciplinary Research in the Sciences: Implications for Library Organization Julie M. Hurd

Bibliographic Instruction: The Views of Academic Special and Public Librarians Roma Harris

The Use of Books within the Library Jeff Selth, Nancy Koller, and Peter Briscoe

Addressing Cultural Diversity in Academic and Research Libraries Otis A. Chadley

The Role, Status, and Working Conditions of Paraprofessionals: A National Survey of Academic Librarians

Larry R. Oberg, Mark E. Mentges, P. N. McDermott, Vitoon Harusadangkul 